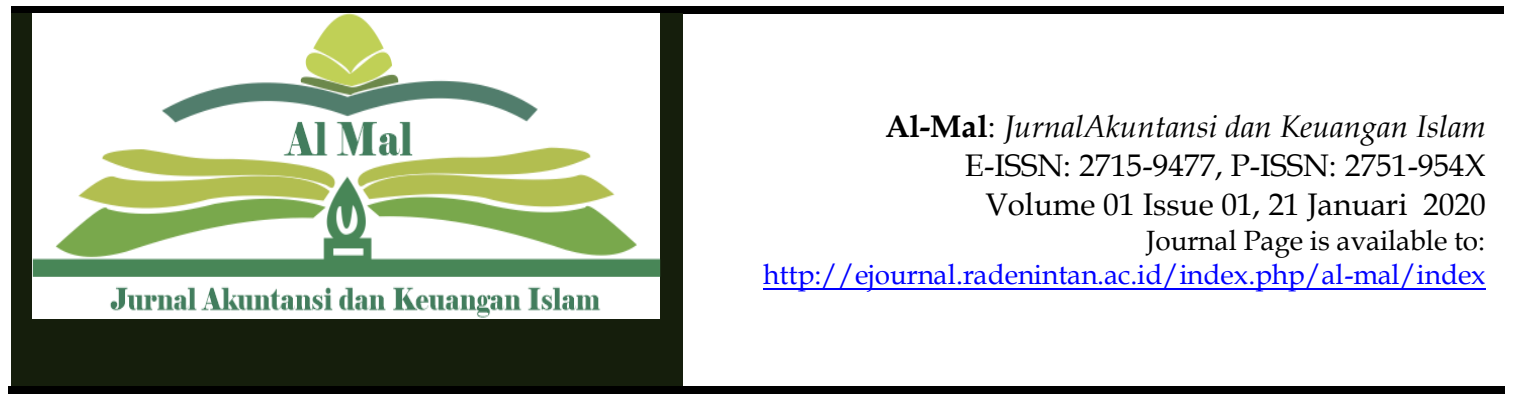

\title{
Analisis Perencanaan Pengelolaan Keuangan Desa Jungai Kecamatan Rambang Kapak Tengah Kota Prabumulih
}

\section{Citra Etika ${ }^{*}$}

1* Departement of Economics, Faculty Economic and Bussines Islamic, Universitas Islam Negeri Raden Intan Lampung, Indonesia

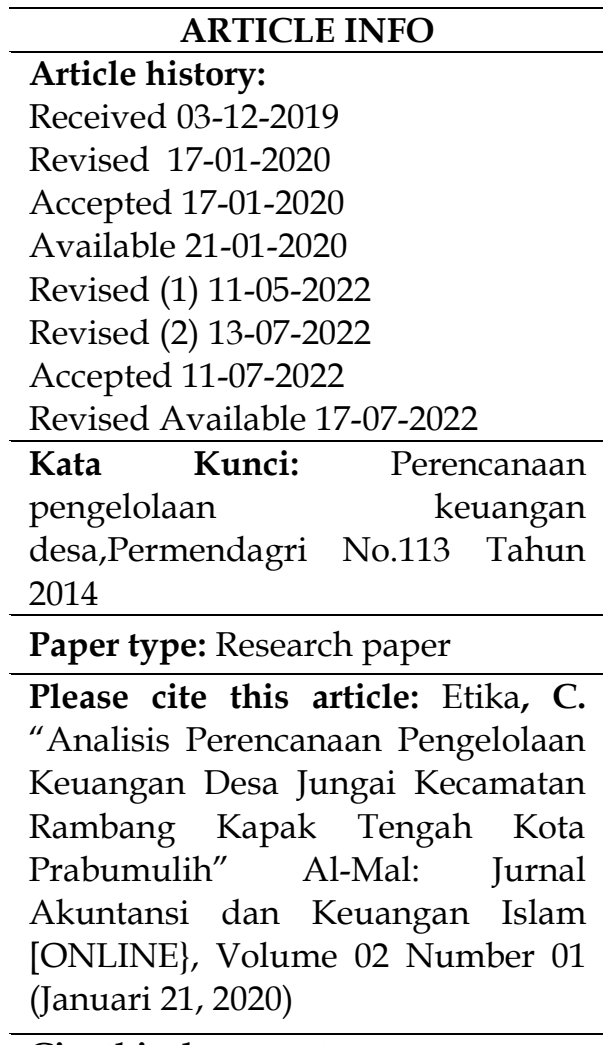

Cite this document:

Al-Mal 2th edition

*Corresponding author

e-mail: citraetika@gmail.com

\begin{abstract}
ABSTRAK
Penelitian ini bertujuan untuk menganalisa penerapan perencanaan berdasarkan Peraturan Menteri Dalam Negeri Nomor 113 Tahun 2014 dalam pengelolaan keuangan desa di Kecamatan Rambang Kapak Tengah Kota Prabumulih. Metode pendakatan penelitian adalah metode kualitatif deskritif komparatif . Sumber data dihasilkan dari wawancara dan dokumentasi, adapun hasil penelitian ini adanya kesesuaian perencanaan rancangan peraturan desa dengan Kemendagri Nomor 113 Tahun 2014, adanya kesesuaian penyusunan rancangan praturan Desa Jungai dengan Permendagri Nomor 113 Tahun 2014, adanya kesesuaian dalam evaluasi rancangan APBDesa dengan Permendagri Nomor 113 Tahun 2014. Keterbatasan penelitian ini terletak pada wilayah objek pengamatan, sehingga membuka peluang bagi peneliti-peneliti selanjutnya untuk menambahkan objek pengamatan yag lebih luas. Implikasi pada penelitian ini yaitu penerapan peraturan Kemendagri Nomor 113 Tahun 2014 akan membawa dapak positif bagi perencanaan pengelolaan keuangan desa yang maksimal.
\end{abstract}

Page: 1-16

Al-Mal with CC BY license. Copyright (C) 2020, the author(s) 


\begin{abstract}
This study aims to analyze the application of planning based on the Regulation of the Minister of Home Affairs Number 113 of 2014 in village financial management in Rambang Kapak Tengah District, Prabumulih City. The research approach method is a comparative descriptive qualitative method. Sources of data were generated from interviews and documentation, as for the results of this study, there is conformity with the planning of village regulations with the Ministry of Home Affairs Number 113 of 2014, there is conformity of the preparation of the draft regulations of Jungai Village with Permendagri Number 113 of 2014, there is conformity in the evaluation of the APBDesa draft with Permendagri Number 113 of 2014. The limitation of this research lies in the area of the object of observation, thus opening up opportunities for further researchers to add a wider object of observation. The implication of this research is that the application of Ministry of Home Affairs Regulation No. 113 of 2014 will bring positive impacts for maximum village financial management planning.
\end{abstract}

Keywords: Village Financial Management Planning, Permendagri No. 113 Of 2014

\title{
INTRODUCTION
}

Otonomi desa dibentuk dengan tujuan untuk meningkatkan kesejahteraan masyarakat desa dan kualitas hidup masyarakat, serta penangulangan kemiskinan, melalui penyediaan pemenuhan kebutuhan dasar, pembangunan sarana prasarana, pengembangan potensi ekonomi lokal, serta pemanfaatan sumberdaya alam dan lingkungan secara berkelanjutan (Undang-undang Nomor 06 Tahun 2014).

Pelaksanaan otonomi daerah didasarkan atas pertimbangan bahwa daerah lebih mengerti bahkan mampu serta mengetahui kebutuhan masyarakat didaerahnya. Salah satu aspek yang sangat penting untuk diperhatikan dalam pelaksanaan otonomi daerah dan desentralisasi adalah masalah pengelolaan keuangan daerah (Vega Virjinia Orangbio dkk, 2017:53). Tujuan tersebut dapat tercapai apabila desa dapat merapkan keuangan desa berdasarkan Peraturan Menteri Dalam Negeri Nomor 113 Tahun 2014. Pengelolaan keuangan desa yang dimaksud dalam Permendagri Nomor 113 Tahun 2014, pasal 2 bahwa asas 
pengelolaan keuangan desa terdiri dari adanya transparan, akuntabilitas, partisipatif, serta dilakukan dengan tertib dan disiplin.

Pengelolaan keuangan desa tersebut dimulai dari perencanaan, pelaksanaan, penatausahaan, pelaporan dan pertanggungjawaban. Namun, kebijakan dalam mengambil keputusan untuk menjalankan otonomi daerah belum berjalan dengan semestinya, karena masih ada kesenjangan antara masyarakat desa dengan masyarakat kota akibat belum meratanya pembangunan dalam segala bidang (Putri Izatul Azwa Amalia \& Endro Sugiartono, 2021:46).

Dalam pengelolaan keuangan desa aspek perencanaan harus sesuai dengan permendagri agar dapat dipertanggungjawabkan penggunaan dana desa. Menurut Yuliansyah dan Rusmianto (2016:18) secara dokumentatif, perencanaan dan pelaksanaan pembangunan desa tertuang dalam Rencana Pembangunan Jangka Menengah Desa (RPJMDesa), Rencana Kerja Pemerintah Desa (RKPDesa) dan Anggaran Pendapatan dan Belanja Desa (APBDesa). Pengelolaan keuangan desa juga dilakukan oleh desa Jungai Kecamatan Rambang Kapak Tengah Kota Prabumulih, yang dimulai sejak tahun 2015. Pemerintah desa dalam mengurus semua urusan pemerintahan dan kepentingan masyarakat setempat, tentunya memerlukan pendapatan agar dapat mencapai tujuan dalam pembangunan dan kesejahteraan desa (Mewvi I. Walukow, 2017:266).

\subsection{Definisi Pengelolaan Keuangan Desa}

Menurut permendagri No. 113 Tahun 2014 Bab 1 Ketentuan umum, pasal 1 ayat bahwa pengelolaan keuangan desa adalah keseluruhan kegiatan yang meliputi perencanaan, pelaksanaan, penatausahaan, pelaporan dan pertanggungjawaban keuangan desa. Sehingga alokasi dana desa ke seluruh desa di Indonesia diharapkan dapat menunjang 
pembangunan akses jalan pedesaan, pengembangan program desa, saran dan prasarana, ekonomi masyarakat serta kebudayaan (Muh. Tahir dkk, 2019:2).

\subsection{Definisi Penyusunan Rancangan Peraturan Desa}

Tahapan-tahapan pengelolaan keuangan desa tertuang didalam Permendagri No. 113 Tahun 2014 Tentang Pengelolaan Keuangan Desa yang meliputi perencanaan, pelaksanaan, penatausahaan, pelaporan, dan pertanggungjawaban keuangan desa (Muhammad Yusuf dkk, 2021:88). Menurut Permendagri No. 113 Tahun 2014 Bab V Pengelolaan bagian kesatu pasal 20 menyatakan bahwa:

a. Sekretaris Desa menyusun rancangan peraturan desa tentang APBDES berdasarkan RKPDES tahun berkenaan.

b. Sekretaris Desa menyampaikan rancangan Peraturan Desa tentang APBDesa kepada Kepala Desa.

c. Ranangan peraturan Desa tentang APBDesa sebagaimana dimaksud pada ayat (2) disampai oleh Kepala Desa kepada Badan Permusyawaratan Desa untuk dibahas dan disepakati bersama.

d. Rancangan Peraturan Desa tentang APBDesa disepakati bersama sebagaimana dimaksud pada ayat (3) paling lambat bulan Oktober tahun berjalan.

\subsection{Definisi Evaluasi Rancangan Peraturan Desa}

Menurut Permendagri No. 113 Tahun 2014 Bab V Pengelolaan bagian kesatu pasal 21 menyatakan bahwa:

a. Rancangan Peraturan Desa tentang APBDES yang telah disepakati bersama sebagaimana dimaksud pada pasal 20 ayat (3) disampaikan oleh kepala desa kepada bupati/walikota melalui camat atau sebutan lain, paling lambat 3 (tiga) hari sejak disepakati untuk dievaluasi

b. Bupati/Walikota menetapkan hasil evaluasi rancangan APBDES sebagaimana dimaksud pada ayat 1 (satu) paling lama 20(dua puluh) 
hari kerja sejak diterimanya rancangan peraturan desa tentang APBDesa

c. Dalam hal bupati atau walikota tidak memberikan hasil evaluasi dalam batas waktu sebagaimana dimaksud pada ayat 2 (dua) peraturan desa tersebut berlaku dengan sendirinya.

d. Dalam hal Bupati/Walikota tidak memberikan hasil evaluasi dalam batas waktu sebagaimana dimaksud pada ayat (2) Peraturan Desa tersebut berlaku dengan sendirinya.

e. Dalam hal Bupati/Walikota menyatakan hasil evaluasi rancangan desa tentang APBDesa tidak sesuai dengan kepentingan umum dan peraturan perundang-undangan yang lebih tinggi, kepala desa melakukan penyempurnaan paling lambat 7 (tujuh) hari kerja terhitung sejak diterimanya hasil evaluasi.

\subsection{Definisi Rencana Pembangunan Jangka Panjang}

Rencana pembangunan jangka menengah desa berdasarkan berdasarkan Peraturan Pemerintah nomor 43 Tahun 2014 adalah rencana pembangunan desa untuk jangka waktu enam tahun yang mana rancangan ini memuat visi dan misi kepala desa, arah kebijakan pembangunan desa serta rencana kegiatan, meliputi bidang penyelenggaraan pemerintah, pelaksanaan pembangunan desa, pembinaan masyarakat desa dan pemberdayaan masyarakat desa. Hamzah (2015) menyatakan rencana pembangunan jangka menengah desa bertujuan untuk :

a. Mewujudkan perencanaan pembangunan desa sesuai dengan kebutuhan masyarakat dan keadaan setempat.

b. Menciptakan rasa memiliki dan tanggungjawab masyarakat terhadap program pembangunan didesa.

c. Memelihara dan mengembangkan hasil-hasil pembangunan di desa. 
d. Menumbuhkembangkan dan mendorong peran serta masyarakat dalam membangun desa.

\subsection{Definisi Rencana Kerja Pemerintah Desa}

Menurut permendagri 113 tahun 2014, Rencana Kerja Pemerintah Desa merupakan penjabaran dari RPJMDESA untuk jangka waktu satu tahun yang memuat kerangka ekonomi desa dengan mempertimbangkan kerangka pendanaan yang di muthakirkan program prioritas pembangunan desa, rencana kerja dan pendanaan serta pemikiran maju, baik yang dilaksanakan langsung oleh pemerintah desa maupun yang ditempuh dengan mendorong partisipasi masyarakat dengan mengacu kepada rencana kerja pemerintah daerah dan RPJMDES.

Rencana pembangunan desa untuk jangka waktu 6 (enam) tahun, yaitu disusun berdasarkan rancangan RPJM Desa yang memuat visi dan misi Kepala Desa, arah kebijakan pembanguna Desa, serta rencana kegiatan yang meliputi bidang penyelenggaraan Pemerintahan Desa, pelaksanaan pembangunan Desa, pembinaan kemasyarakatan Desa, dan pemberdayaan masyarakat Desa (Wiwin Deri Fitriani dkk, 2018:49). Sehingga dalam rangka melayani publik yaitu masyarakat, dibutuhkan aparat desa yang handal ditunjang sarana dan prasarana yang cukup menuju tata kelola yang baik dengan harapan pelaksanaan lebih terarah (Rudi Rusiyanto, 2020:146).

Pemerintah Desa harus bisa menerapkan asas akuntabilitas, efektivitas, dan efisiensi dalam penyelengaraan pemerintahan khususnya dalam pengelolaan Dana Desa agar dapat dipertanggungjawabkan kepada masyarakat dan menghindari potensi penyalahgunaan anggaran (Muhammad Luthfi Iznillah dkk, 2018:31).

\subsection{Definisi Anggaran Pendapatan Belanja Desa}

Menurut permendagri 113 Tahun 2014 Anggaran pendapatan dan belanja desa (APBDESA) adalah rencana keuangan tahunan pemerintah 
desa. Pasal 8 menyatakan APBDES terdiri atas pendapatan desa, belanja desa, dan pembiayaan desa. Pengoptimalan potensi pendapatan daerah salah satunya adalah dengan memberi porsi belanja daerah yang lebih besar untuk sektor produktif, maupun melalui ekstensifikasi dan intensifikasi sumber-sumber PAD yang baru dalam upaya membiayai program dan kegiatan pemerintah daerah dalam menjalankan roda pemerintahan maupun pelaksanakan pembangunan daerah (Halomoan Hutajulu, 2014: 22). Selain itu, pemberian kesempatan yang lebih besar bagi desa untuk mengurus tata pemerintahannya sendiri serta pemerataan pelaksanaan pembangunan diharapkan dapat meningkatkan kesejahteraan dan kualitas hidup masyarakat desa (Hisbul Manto \& Abdul Qodir Djaelani, 2017:41).

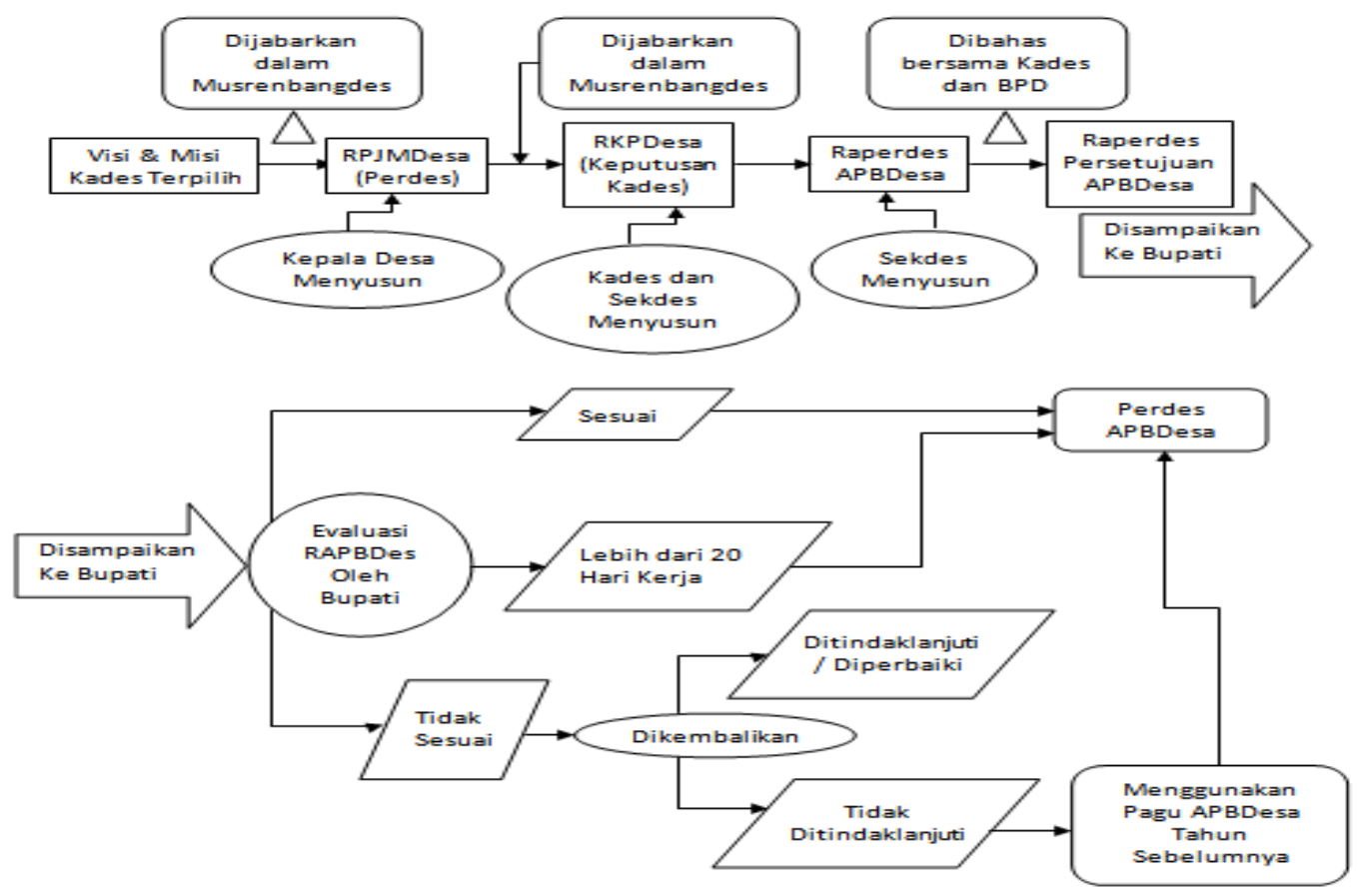

Gambar 1. Proses Penyusunan APBDesa

\section{METHODS}

Jenis penelitian yang digunakan dalam penelitian ini adalah penelitian kualitatif. Lokasi penelitian di Desa Jungai Kecamatan 
Rambang Kapak Tengah. Waktu penelitian 25 Januari sampai dengan 25 Juni 2018. Data yang digunakan adalah data primer, yang berupa hasil wawancara dan data sekunder berupa RKPDesa dan APBDesa Desa Jungai Tahun 2017. Metode analisis yang digunakan adalah deskriptif kualitatif komparatif yakni membandingkan pengelolaan desa Jungai kecamatan rambang kapak tengah kota Prabumulih dengan permendagri nomor 113 tahun 2014.

\section{RESULT AND DISCUSSION}

Mekanisme perencanaan didesa Jungai kecamatan rambang kapak tengah kota Prabumulih mulai dari penyusunan perencanaan jangka menengah desa (RPJMDESA) yang ditetapkan dalam bentuk peraturan desa yang disesuaikan dengan visi misi dan gagasan kepala desa, agar desa Jungai menjadi lebih sejahtera. Rencana pembangunan jangka menengah desa (RPJMDESA) dibuat untuk jangka waktu enam tahun mulai dari tahun 2016 sampai dengan tahun 2021. Selanjutnya kepala desa membentuk tim penyusunan RKPDes, tim penyusunan RKPDes merumusan perencanaan melalui musrenbangdes. Musrenbangdes penyusunan RKPDesa dilakukan pada bulan januari yang dihadiri oleh perangkat desa (kepala desa, bendahara desa, sekretaris desa, kaur perencanaan, kaur pembangunan, kaur kesejahteraan masyarakat, kaur umum, kaur keuangan dan kaur pembangunan), BPD, karang taruna dan tokoh masyarakat, masyarakat desa, kepala dusun diwilayah desa Jungai. Pengelolaan dana desa yang baik tidak terlepas dari proses perencanaan pengelolaan dana desa yang baik. Proses tersebut membutuhkan sumber daya manusia, dalam hal ini perangkat desa yang memahami proses perencanaan dan akuntansi secara optimal (Berlian Putri Maha Rini \& Rochmad Bayu Utomo, 2019:133). Membahas tentang laporan pelaksanaan kegiatan, tanggapan atau masukan masyarakat atas laporan pelaksanaan 
kegiatan, pembahasan tanggapan dan masukan masyarakat, merumusan tindaklanjut dan masukan masyarakat. Setelah dilakukan pembahasan dan diskusi, selanjutnya seluruh peserta musrenbangdes menyetujui serta memutuskan beberapa ketetapan yaitu pertama penggunaan alokasi dana desa yang dialokasikan untuk bidang penyelenggaraan desa, dan bidang pembinaan masyarkat desa, kedua penggunaan dana desa yang dialokasikan untuk bidang pembangunan desa dan bidang pemberdayaan masyarakat. Namun, pada aspek pengawasan permasalahan yang dihadapi atas pengelolaan keuangan dana desa yaitu: pertama, efektivitas inspektorat daerah dalam melakukan pengawasan terhadap pengelolaan keuangan di desa masih rendah; kedua, saluran pengaduan masyarakat tidak dikelola dengan baik oleh semua daerah; dan ketiga, ruang lingkup evaluasi dan pengawasan yang dilakukan oleh camat belum jelas (Gayatri dkk, 2017:177).

Selanjutnya penuyusunan APBDes desa Jungai kecamatan rambang kapak tengah berdasarkan RKPDesa yang telah disusun, yang dibuat oleh sekretaris desa. APBDes berisi tentang pendapatan desa (pendapatan asli desa, dana transfer dan pendapatan lainnya) dan belanja desa. Belanja desa dikelompokan menjadi lima, yakni :

1. Bidang penyelenggaraan pemerintah desa.

2. Bidang pelaksanaan pembangunan desa.

3. Bidang pembinaan kemasyarakatan desa.

4. Bidang pemberdayaan masyarakat desa.

5. Belanja tak terduga.

Perencanaan pengelolaan keuangan desa Jungai Kecamatan Rambang Kapak Tengah Kota Prabumulih telah sesuai dengan Permendagri Nomor 113 tahun 2014 yakni, perencaan diawali dengan penyusunan RPJMDes yang dibuat oleh kepala desa selama 6 (enam) tahun (2016-2021), selanjutnya dibuat RKPDesa yang berdasarkan hasil 
musrenbangdes desa Jungai Kecamatan Rambang Kapak Tengah Kota Prabumulih pada bulan januari. RKPDesa Jungai menjadi pedoman untuk penyusunan anggaran pendapatan dan belanja desa (APBDesa) desa Jungai Kecamatan Rambang Kapak Tengah Kota Prabumulih.

Penyusunan perancangan peraturan desa disusun oleh sekretaris desa yang berupa anggaran pendapatan dan pendapatan desa (APBDesa). APBDesa disusun berdasarkan RPKDesa yang telah dibuat berdasarkan hasil musrenbangdesa. Setelah disusun rancangan peraturan APBDesa diserahkan ke kepala desa selanjutnya kepala desa menyampaikan rancangan peraturan tersebut kepada badan permusyawaratan desa. Rancangan APBDesa disepakati pada bulan februari.

Evaluasi rancangan peraturan Desa Jungai Kecamatan Rambang Kapak Tengah Kota Prabumulih telah sesuai dengan Permendagri Nomor 113 Tahun 2014, yakni APBDesa Desa Jungai Kecamatan Rambang Kapak Tengah Kota Prabumulih setelah dibuat diserahkan ke pendamping desa, kecamatan, Dinas Pemberdayaan Masyarakat Desa (DPMD) Kota Prabumulih untuk dievaluasi. Bentuk evaluasi yang dilakukan oleh camat, pendamping desa, dan DPMD berupa evaluasi secara lisan dan selanjutnya diperbaiki oleh sekretaris desa. Setelah APBDesa diperbaiki diserahkan kembali ke pendamping desa, camat dan DPMD untuk disahkan. Faktor penghambat perencanaan keuangan desa keuangan desa jungai, yaitu :

1. Evaluasi hanya secara lisan yang dilakukan oleh camat dan DPMD.

2. Kurangnya pengawasan dari masyarakat dalam proses perencanaan pengelolaan keuangan desa.

Menurut Hoesada (2016: 2 hal 312) menyatakan adanya ketidak konsistenan rencana pembangunan jangka menengah daerah (RPJMDaerah) dengan anggaran pendapatan dan belanja (APBDaerah). 
Hal ini terjadi juga di Desa Jungai Kecamatan Rambang Kapak Tengah Kota Prabumulih, dimana Rencana kerja pemerintah desa yang merupakan perpanjangan desa dari rencana pembangunan jangka menengah desa (RPJMDesa) tidak sesuai dengan anggaran pendapatan dan belanja desa (APBDesa) yakni pada belanja desa bidang pembinaan masyarakat desa dan bidang pemberdayaan masyarakat dengan nominal yang berbeda pada RKPDesa yang telah ditetapkan. Pada dasarnya pelaksanaan APBDes dilakukan oleh pemerintah desa sendiri dimana pemerintah daerah sudah memberi kewenangan yang penuh kepada Kepada Desa untuk mengelola keuangannya secara bertanggung jawab (Jeacklin Valenia Mamuaya dkk, 2017:1021). Pengelolaan Keuangan Desa. Keuangan desa tersebut dikelola melalui kegiatan yang meliputi perencanaan, penganggaran, penatausahaan, pelaporan, pertanggungjawaban dan pengawasan keuangan desa yang dilakukan oleh Kepala Desa yang dibantu oleh Pelaksanan Teknis Pengelolaan Keuangan Desa (PTPKD) (Elsa Dwi Wahyu Dewanti dkk, 2016:2).

Terdapat dua masalah utama pelaksanaan dana desa, yakni: pertama, pemberian jumlah dana desa yang semakin besar setiap tahunnya akan tetapi tidak diimbangi dengan kapasitas dan kapabilitas sumber daya manusia (aparatur desa) di tingkat desa dalam pengelolaan keuangan desa. Kedua, minimnya keterlibatan masyarakat dalam perencanaan dan penyusunan APBDes dan RABDes, serta pengawasan penggunaan dana desa (Nardi Sunardi \& Rosa Lesmana, 2020:278). Setiap desa memiliki karakteristik dan jenis yang berbeda-beda. Namun, hal itu tidak menjadi penghalang bagi berjalannya roda kepemerintahan.Setiap desa diberikan hak otonom untuk mengurus dan mengelola pemerintahannya sendiri (Lianatus Sholichah \& Bambang Suryono, 2018:2). Oleh karena itu, sumber daya manusia sebagai pengelola 
keuangan pemerintah desa wajib meningkatkan kualitas. Hal ini dikarenakan, sesuai dengan Undang-Undang Nomor 6 tahun 2014 Tentang Desa, bahwa pengelolaan keuangan desa hingga mencapai Rp 1 Miliar harus dikelola dengan profesional, agar tidak terjadi kesalahan dan penyimpangan yang dilakukan aparatur pemerintah desa (Putu Fany Nadila dkk, 2019:3).

Menurut penelitian Ismail Alfaruqi \& Ika Kristianti (2019) potensi kecurangan dapat ditemukan dalam proses pembangunan dan penyusunan pelaporan keuangan misalnya pemalsuan, manipulasi data atau mengubah dokumen-dokumen pendukung dalam menyusun laporan keuangan. Bermacam-macam modus dilakukan oleh pelaku korupsi di pemerintahan desa, sebagian besar merupakan praktik penyalahgunaan anggaran sebanyak 51 kasus, 32 kasus penggelapan, laporan fiktif dengan 17 kasus, kegiatan atau proyek fiktif 15 kasus dan sebanyak 14 kasus pembengkakan anggaran (Ismail Alfaruqi \& Ika Kristianti, 2019: 200). Sehingga untuk saat ini kendala umum yang dirasakan oleh sebagian besar desa adalah terkait pengelolaan keuangan yang baik dan benar yang sering kali tahapan perencanaan, pelaksanaan, penatausahaan, pelaporan dan pertanggungjawaban tidak sesuai dengan kenyataan di lapangan (T. Fitrawan Mondale dkk, 2017:197).

Pemberian kesempatan yang lebih besar bagi desa untuk mengurus tata pemerintahannya sendiri serta pemerataan pelaksanaan pembangunan diharapkan dapat meningkatkan kesejahteraan dan kualitas hidup masyarakat desa hal ini sebagai bentuk transparasi yang harus dilakukan oleh pemerintah desa. Selain itu, memberikan pertanggungjawaban atau menjawab dan menerangkan kinerja dan tindakan seseorang merupakan bentuk kewajiban akuntabilitas yang harus diterapkan dan juga adanya partisiasi bahwa setiap warga mempunyai hak untuk terlibat dalam setiap pengambilan keputusan 
dalam kegiatan yang diselenggarakan oleh pemerintah desa dimana mereka tinggal baik secara langsung maupun tidak langsung (Ifatul Ambar Zulaifah, 2020:4).

\section{CONCLUSION}

Berdasarkan hasil penelitian yang telah dilakukan oleh penulis maka dapat ditarik kesimpulan sebagai berikut Adanya kesesuaian perencanaan rancangan peraturan desa dengan Kemendagri Nomor 113 Tahun 2014. Adanya kesesuaian penyusunan rancangan praturan Desa Jungai dengan Permendagri Nomor 113 Tahun 2014. Adanya kesesuaian dalam evaluasi rancangan APBDesa dengan Permendagri Nomor 113 Tahun 2014.

\section{IMPLIKASI}

Implikasi pada penelitian ini yaitu penerapan peraturan Kemendagri Nomor 113 Tahun 2014 akan membawa dapak positif bagi perencanaan pengelolaan keuangan desa yang maksimal.

\section{REFERENCES}

Alfaruqi, I., \& Kristiani, I. (2019). Analisis Potensi Kecurangan Dalam Pengelolaan Keuangan Desa (Studi: Desa Kesongo, Kecamatan Tuntang, Kabupaten Semarang, Jawa Tengah). Jurnal Akuntansi, 11(2).

Amalia, P. I. A., \& Sugiartono, E. (2021). Perencanaan Pengelolaan Keuangan Desa Studi Kasus Pada Desa Tembokrejo Kecamatan Gumukmas Kabupaten Jember). Jurnal Akuntansi Terapan dan Bisnis, 1(1).

Dewanti, E. D. W., Sudarno, \& Kurrohman, T. (2016). Analisis Perencanaan Pengelolaan Keuangan Desa di Desa Boreng (Studi Kasus Pada Desa Boreng Kecamatan Lumajang Kabupaten Lumajang), UNEJ Press. 
Fitriani, W. D., Susyanti, J., \& ABS, M. K. (2018). Analisis Perencanaan Pengelolaan Keuangan Desa Menurut Peraturan Menteri Dalam Negeri Nomor 113 Tahun 2014 (Studi Kasus di Desa Masangan Wetan Kecamatan Sukodono Kabupaten Sidoarjo Periode 2017). Jurnal Ilmiah Riset Manajemen, 7(13).

Gayatri, G., Latrini, M. Y, \& Widhiyani, N. L. S. (2017). Transparansi dan Akuntabilitas Pengelolaan Keuangan Dana Desa untuk Mendorong Kemandirian Masyarakat Pedesaan. Jurnal Ekonomi Kuantitatif Terapan.

Hoesada, Jan. 2016. Bunga Rampai Akuntansi Pemerintah, Jilid 1, Salemba Empat, Jakarta.

Hutajulu, H. (2014). Analisis Pengelolaan Keuangan Daerah di Kota Jayapura Padaa Era Otonomi Khusus. Jurnal Ekonomi dan Bisnis, 17(1).

Iznillah, M. L., Hasan, A., \& Mutia, Y. (2018). Analisis Tranparansi dan Akuntabilitas Pengelolaan Keuangan Desa di Kecamatan Bengkalis. Jurnal Akuntansi (Media Riset Auntansi \& Keuangan), 7(1).

M.I. Waliko, L. Kalangi, dan S. Pinatik. 2017. Analisis Perencanaan Pengelolaan Keuangan Desa Sesuai Dengan Peraturan Menteri Dalam Negeri Nomor 113 Tahun 2014 Di Desa Kauneran 1 Kecamatan Sonder Kabupaten Minahasa. Jurnal Riset Akuntansi Going Concern, 12(2), hal.266-275.

Maharini, B. P., \& Utomo, R. B. (2019). Analisis Perencanaan Pengelolaan Dana Desa (Studi Pada Dana Desa Tahun 2018 di Desa Banguntapan, Kecamatan Banguntapan, Kabupaten Bantul). Jurnal Riset Akuntansi Mercu Buana, 5(2).

Mamuaya, J. V., Sabijono, H., \& Gamaliel, H. (2017). Analisis Pengelolaan Keuangan Desa Berdasarkan Permendagri No. 113 Tahun 2014 (Studi Kasus di Desa Adow Kecamatan Pinolosian Tengah 
Kabuoaten Bolaang Mongondow Selatan). Jurnal EMBA: Jurnal Riset Ekonomi, Manejeman, Bisnis dan Akuntansi, 5(2).

Manto, H., \& Djaelani, A. Q. (2017). Analisis Perencanaan Pengelolaan Keuangan Desa (Studi Pada Desa Trapang Kecamatan Banyuates Kebupaten Sampang). Jurnal Ilmiah Riset Manajemen, 6(4).

Mondale, T. F., Aliamin, A., \& Fahlevi, H. (2017). Analisis Problematika Pengelolaan Keuangan Desa (Studi Perbandingan pada Desa Blang Kolak I dan Desa Blang Kolak II, Kabupaten Aceh Tengah). Junral Perspektif Ekonomi Darussalam, 3(2).

Orangbio, V. V., Tinangon, J. J., \& Gerungai, N. (2017). Analisis Perencanaan dan Pertanggungjawaban APBDes Menurut Peraturan Menteri Nomor 113 Tahun 2014 Dalam Upaya Meningkatkan Pembangunan Desa. Going Concern: Jurnal Riset Akuntansi, 12(2).

Peraturan Menteri Dalam Negeri Nomor 113 Tahun 2014 tentang Pengelolaan Keuangan Desa.

Rusiyanto, R. (2020). Analisis Perencanaan Keuangan Desa Besuki Kecamatan Besuki Kabupaten Tulungagung. Jurnal Benefit, 7(2).

Sari, P. F. N. P., Sumariani, N. W. W., Cahyani, N. K. R., \& Dewi, K. Y. W. (2019). Analisis Pengelolaan Keuangan Desa Buruan, Kecamatan Penebel Kabupaten Tabanan. Jurnal Ilmiah Akuntansi dan Humanika, $7(2)$.

Sholichah, L., \& Suryono, B. (2018). Analisis Perencanaan Pengelolaan Keuangan Desa Kedamean Kecamatan Kedamean Kabupaten Gresik. Jurnal Ilmu dan Riset Akuntansi (JIRA), 7(4).

Sunardi, N., \& Lesmana, R. (2020). Pelaksanaan Alokasi Dana Desa Terhadap Manajemen Keuangan Desa Terhadap Manajemen Keuangan Desa Dalam Meningatkan Efektivitas Program Desa Sejahtera Mandiri di Desa Cihambulu, Kec. Paburan, Kab. Subang. Jurnal SEKURITAS (Saham, Ekonomi, Keuanagn, dan Investasi), 3(3). 
Tahir, M., Anwar, A., \& Dinakir, S. (2019). Analisis Pengelolaan Keuangan Dana Desa di Desa Bululoe Kecamatan Turatea Kabupaten Jeneponto (Doctoral Dissertation, Universitas Negeri Makassar).

Tim Penyusun Badan Diklat Provinsi Kalimantan Barat. 2015. Modul Keuangan Desa. http://bandiklat. kalbarprov.go.id/download_modul.php?id=61, diakses 3April 2015. Undang-Undang Republik Indonesia Nomor 06 Tahun 2014 tentang Desa Walukow, M. I., Kalangi, L., \& Pinatik, S. (2017). Analisis Perencanaan Pengelolaan Keuangan Desa Sesuai Dengan Peraturan Menteri Dalam Negeri Nomor 113 Tahun 2014 di Desa Kauneran I Kecamatan Sonder Kabupaten Minahasa. Going Concern Jurnal Riset Akuntansi, 12(2).

Yuliansyah, dan Rusmianto. 2016. Akuntansi Desa. Salemba Empat. Jakarta Yusuf, M, Romadhon, R., \& Kaukab, M. E. (2021). Analisis Perencanaan Pengelolaan Keuangan Desa. Jurnal Capital: Kebijakan Ekonomi, Manajemen dan Akuntansi, 3(1).

Zulaifah, I. A. (2020). Perencanaan Pengelolaan Keuangan Desa (Studi Kasus Pada Desa Jlumpang, Kecamatan Bancak, Kabupaten Semarang). Jurnal Akuntansi dan Pajak, 21(1). 